\title{
Pozycja i ranga przedsiębiorczości w edukacji geograficznej \\ w szkole podstawowej w kontekście zmian edukacyjnych
}

DOI: $10.47050 / 65591760.168-183$

Monika Borgiasz-Stepaniuk

Edukacja, a szczególnie nauczanie elementów przedsiębiorczości, tworzy możliwości rozwoju dla młodego człowieka, który musi funkcjonować we współczesnym świecie. Kształcenie młodzieży w sferze przedsiębiorczości to determinanta wzrostu gospodarczego kraju. W dobie konkurencyjności rozwijanie u młodych ludzi umiejętności i zdolności innowacyjnych wpływa na przygotowanie ich do dorosłego życia, w dynamicznie zmieniającej się rzeczywistości. Oznacza to wprowadzenie do nauczania treści przedsiębiorczych od najwcześniejszych lat szkolnych. Problemem badawczym niniejszej pracy jest analiza podstawy programowej z geografii zreformowanej szkoły podstawowej pod kątem przedsiębiorczości. Autorka koncentruje swoją uwagę na treściach z zakresu przedsiębiorczości, które mogą być realizowane na różnych poziomach nauczania geografii w szkole podstawowej. W niniejszym opracowaniu przeanalizowano treści geograficzne pod kątem przedsiębiorczości, wskazano umiejętności, które uczeń powinien osiągnąć w trakcie ich realizowania, oraz podano przykłady prezentacji tematyki przedsiębiorczości na lekcjach. Aktywność, otwartość, liberalizm, ciekawość świata oraz pokonywanie ograniczeń to tylko niektóre z elementów pojawiających się w edukacji z przedsiębiorczości w zreformowanej szkole podstawowej.

\section{Słowa kluczowe:}

edukacja

geografia

przedsiębiorczość 


\section{Position and rank of entrepreneurship in geographic education in primary school in the context of educational changes}

DOI: 10.47050/65591760.168-183

Monika Borgiasz-Stepaniuk

Education, and especially the teaching of entrepreneurial elements, creates opportunities for development for a young man who must function in the modern world. Educating young people in the sphere of entrepreneurship is the determinant of the country's economic growth. In the era of competitiveness, developing young people's skills and innovative abilities influences their preparation for adult life, in a dynamically changing reality. This means introducing entrepreneurial content into teaching from the earliest school years. The research problem of this study is the analysis of the core curriculum in the geography of the reformed primary school in terms of entrepreneurship. The author focuses her attention on entrepreneurial content that can be implemented at various levels of geography teaching in a primary school. This study analyzes geographic content in terms of entrepreneurship, indicates the skills that a student should achieve during their implementation and gives examples of presentation of the subject of entrepreneurship in the classroom. Activity, openness, liberalism, curiosity of the world and overcoming limitations are just some of the elements emerging in education from entrepreneurship in a reformed primary school.

Keywords:

education

geography

entrepreneurship 


\section{Wstęp}

Przedsiębiorczość jest interpretowana jako zachowania, które wyrażają się w predyspozycjach człowieka. Są to między innymi: umiejętność dostosowania się do zmieniających się warunków otoczenia, wykonywania określonych działań i dopasowywanie ich do odpowiednich celów. Warunkowana jest licznymi czynnikami, które mają wpływ na jej rozwój. Rzeczywiste zachowania przedsiębiorcze są odmienne i zależne od zakresu analizy oraz odpowiedniego rozróżnienia.

Dyskusja na temat przedsiębiorczości pokazuje, że jest ona określana $z$ jednej strony naturalnymi umiejętnościami, a z drugiej - pozytywnymi i pożądanymi czynnikami przestrzennymi, które tę przedsiębiorczość tworzą, aktywizują, ale także spowalniają.

W tym miejscu pojawia się pytanie, czy przedsiębiorczość to wartość wrodzona czy nabyta. Literatura specjalistyczna potwierdza, że człowiek nie rodzi się przedsiębiorczy. Można w tym miejscu powołać się na słowa Alberta Shapero (1982), który twierdzi, że człowiek staje się przedsiębiorczy. Jego zdaniem cechy, które wyróżniają osobę przedsiębiorczą od innych, nie mają związku z dziedzicznością. Zdobywa się je poprzez naukę i doświadczenie oraz osobistą selekcję i postanowienia. W trakcie edukacji i zdobywania doświadczenia ludzie osiągają umiejętności przedsiębiorcze, stanowiące elementy wyuczone. Potrzebna $w$ byciu przedsiębiorczym jest determinacja w edukacji (Shapero 1982).

Można więc przyjąć, że zdobywanie wiedzy oraz kształtowanie określonych umiejętności robi z człowieka osobę przedsiębiorczą. Działania przedsiębiorcze są konsekwencją połączenia rzeczywistości wewnętrznej i zewnętrznej oraz wzajemnego ich krzyżowania się. Następstwami takiego procesu może być rozwój przedsiębiorczości, ale także jej ograniczenie.

Czynnikami zewnętrznymi, które determinują przedsiębiorczość, są edukacja i jej organizacja. Wiedza jako element mający wpływ na ożywienie społeczno-gospodarcze jest kapitałem intelektualnym we współczesnej gospodarce. Tworzenie i wykorzystywanie wiedzy warunkuje postęp technologiczny, a także gospodarczy i społeczny. Poziom edukacji jest czynnikiem mającym wpływ na konkurencyjność regionu i jego poziom rozwoju. Poprawia jakość życia i zwiększa korzyści społeczne (Kabaj 1997; Grodzicki 2000; Zajączkowska-Jakimiak 2002; Wieloński 2003). 
Autorka niniejszej publikacji skupia się na elementach przedsiębiorczych, które pojawiają się w toku edukacji geograficznej w zreformowanej szkole podstawowej. Nauka na tym poziomie jest znacząca ze względu na dużą chęć poznawczą dzieci oraz możliwości sterowania procesem nauczania na tym etapie nauki. Dzięki kształtowaniu postaw przedsiębiorczych od najwcześniejszych lat szkolnych młody człowiek będzie coraz bardziej świadomy zdobywanej wiedzy i umiejętności, co pozwoli mu na podjęcie wyzwań cywilizacyjnych. Kształtowanie postaw przedsiębiorczych od najmłodszych lat przygotowuje dziecko do znalezienia się w zmieniającej się rzeczywistości oraz pomaga aktualizować wiedzę i umiejętności w toku uczenia się (Borowiec, Rachwał 2011). Im wcześniej postawy przedsiębiorcze będą wykształcane, tym szybciej staną się one cechami osobowości danego człowieka.

\section{Kształtowanie postaw przedsiębiorczych}

Przedsiębiorczość jako pojęcie związane z nowymi możliwościami odgrywa dużą rolę w rozwoju świata. Zarówno współczesna gospodarka, jak i społeczeństwo zmieniają się pod wpływem aktywności i wszelkiego rodzaju inicjatyw mających swoje źródło w ludziach przedsiębiorczych. To właśnie oni w sposób bezpośredni biorą udział w zmianach społeczno-gospodarczych i kształtują współczesność. Ich wiedza, umiejętności i zdobywane doświadczenie wpływają na obraz określonego miejsca, a także danego społeczeństwa.

Kształtowane postawy przedsiębiorcze, cechy charakteru i zdolności pociągają za sobą działania decydujące o rozwoju danego regionu. W tym miejscu można sobie zadać pytanie: Czy każdy może być przedsiębiorczy? Wiadomo już, że przedsiębiorczość jest cechą nabytą, a nie wrodzoną. Nie ma w literaturze specjalistycznej określonego wzorca osoby przedsiębiorczej. Niełatwo jest zatem opisać atrybuty, które stanowią o zachowaniach przedsiębiorczych. Mimo wszystko można wyróżnić te cechy, które przeważają i są właściwe dla ludzi przedsiębiorczych. Są to dominanty aktywne, niestandardowe i buntownicze (Safin 2004).

Osoba przedsiębiorcza odznacza się takimi przymiotami, które są różnorodnie oceniane przez określone zbiorowości społeczne. Mogą być klasyfikowane jako cechy wartościowe i pożyteczne, ale także jako elementy ograniczające postęp regionalny. Tworzą pozytywne modele lub negatywne schematy (Kets de Vries 1985). 
W literaturze tematycznej wskazuje się, że wartościowe postawy przedsiębiorcze można rozwinąć i umocnić poprzez edukację. Człowiek rozwijający postawy przedsiębiorcze musi umiejętnie i rzeczowo ocenić własne zdolności oraz możliwości, konsekwentnie wzbogacając swoją wiedzę oraz umiejętności (Otoliński 1996).

Tego rodzaju starania przeprowadza się dzięki edukacji. Dotyczy to zarówno osób młodych, wchodzących na drogę zawodową, jak i tych, które posiadają już doświadczenie specjalistyczne. Łączenie nauki z rozwijaniem postaw przedsiębiorczych tworzy impulsy pobudzające i uaktywniające rozwój wewnętrzny człowieka, ale także całego społeczeństwa. Ważna jest $w$ tym miejscu zgoda społeczna i szacunek dla osób aktywizujących daną przestrzeń. Kształcenie postaw przedsiębiorczych powinno być postępowaniem wieloletnim i wspomagającym osoby przedsiębiorcze na każdym etapie rozwoju osobistego (National Content Standards for Entrepreneurship Education).

Założenia przedsiębiorczości we współczesnych naukach przekraczają granice nauk ekonomicznych i wchodzą w ramy nauk społecznych. Postawy przedsiębiorcze kształtowane są przez takie elementy, które związane są z otaczającą rzeczywistością. Otoczenie daje zasięg dla pojawiania się dominant wpływających na zachowania człowieka, w tym także działania przedsiębiorcze. Na takim gruncie odpowiednio kształtowane cechy osobowościowe, wspierane wiedzą, mają możliwość rozwijania się w stronę przedsiębiorczości (Kurczewska 2010).

Zakładając, że przedsiębiorczość nie jest cechą wrodzoną, autorka publikacji wychodzi z założenia, że człowiek w trakcie całego życia, zdobywając wiedzę i odpowiednie umiejętności, staje się osobą przedsiębiorczą. Dodatkowo jego postawy oraz relacje z innymi ludźmi mają wpływ na nadawanie kształtu zachowaniom przedsiębiorczym. Drugi człowiek może mobilizować i wspomagać aktywności przedsiębiorcze, ułatwiając podejmowanie określonych decyzji. Postępowanie przedsiębiorcze jest zależne zarówno od cech osobowościowych człowieka, jak i od elementów kulturowych, które na niego działają. Charakter i predyspozycje w połączeniu z kwalifikacjami i ze zdolnościami tworzą osobę w pełni przedsiębiorczą.

Można więc sformułować hipotezę, że włączanie treści z zakresu przedsiębiorczości do edukacji geograficznej na poziomie szkoły podstawowej oraz odpowiedzialne i umiejętne realizowanie tej tematyki przez nauczycieli geografii zapewnia odpowiednie przygotowanie 
ucznia do poznania, zrozumienia i reagowania na współczesne wyzwania cywilizacyjne.

\section{Przedsiębiorczość w edukacji geograficznej w zreformowanej szkole podstawowej}

Kształcenie w sferze przedsiębiorczości odgrywa obecnie ważną rolę w rozwijaniu społeczeństwa oraz $w$ dynamizowaniu gospodarki. Początki edukacji w kierunku przedsiębiorczości sięgają lat 50. XX w. W $1947 \mathrm{r}$. w Stanach Zjednoczonych zorganizowano pierwszy na świecie kurs z problematyki przedsiębiorczości (Wach 2014).

Rozwijanie przedsiębiorczości obejmuje kształcenie formalne (edukacja szkolna), nieformalne i samokształcenie. Uczenie nieformalne obejmuje region kulturowy, zasady i wzorce społeczne oraz modele rodzinne. Tak pojmowana nauka wzmacnia motywację, stymuluje chęci i określa znaczenie przedsiębiorczości dla rozwoju jednostki oraz całego społeczeństwa.

W literaturze specjalistycznej wyodrębnia się trzy priorytety dotyczące nauczania przedsiębiorczości. Pierwszym z nich jest zdobywanie odpowiedniej wiedzy o przedsiębiorczości. Młodzież spotyka się z elementami, które mogą doprowadzić do osiągnięcia sukcesu. Drugi cel kształcenia w kierunku przedsiębiorczości związany jest z wypracowaniem wśród młodych ludzi postaw pozwalających otworzyć się na innowacje i konkurencyjność rynkową. Trzecia idea to przygotowanie uczniów do przyszłego funkcjonowania we współczesnym systemie gospodarczym. Odpowiednie kompetencje i cechy indywidualne są wymogiem skutecznego i prawdziwego rozwoju. Ważne jest, aby młodzież miała możliwość sprawdzenia tych trzech celów w działaniu, uzyskując odpowiedzi na nurtujące ją pytania (Jack i Anderson 1998; Chen i in. 1998; Gibb 1999; London i Smither 1999; Salomon i in. 2002).

W tym miejscu należy się zastanowić, czy edukacja geograficzna w zreformowanej szkole podstawowej daje możliwości, które pozwolą na wykształcenie u młodego człowieka postaw przedsiębiorczych. Czy wiedza i umiejętności zdobywane na tym etapie kształcenia przygotowują ucznia do przystosowania się do wyzwań współczesnej gospodarki?

W literaturze przedmiotu potwierdzone jest, że kompetencje osiągane na poszczególnych etapach kształcenia są niewystarczające i należy je ciągle uwspółcześniać. Kształtowanie postaw przedsiębiorczych 
na lekcjach geografii już od szkoły podstawowej wpływa na rozwijanie świadomości i potrzeby ciągłego aktualizowania wiedzy i uzyskiwania nowoczesnych umiejętności.

Cechy przedsiębiorcze obejmują nie tylko działalność człowieka, lecz także jego osobowość. Treści realizowane w nauczaniu geografii na etapie szkoły podstawowej mogą rozwijać takie atrybuty przedsiębiorczości jak: kreatywność, zaangażowanie, pracowitość, asertywność, uczciwość, umiejętność koncentracji, otwartość i pewność siebie. Młody człowiek, który od najmłodszych lat zdobywa wiedzę i określone umiejętności, podejmuje działania, osiąga sukcesy i jest otwarty na wyzwania, staje się osobą przedsiębiorczą (Borowiec, Rachwał 2011).

Kształcenie w obszarze przedsiębiorczości korzystnie wpływa na wszystkie dziedziny życia człowieka. Cechy przedsiębiorcze przydatne są nie tylko w działalności gospodarczej, lecz także w codziennym funkcjonowaniu. Ich doskonalenie motywuje i zachęca do działania, ale także rozwija aktywność i kreatywność.

Żeby uzyskać świadome implikacje, edukacja przedsiębiorcza powinna korelować z innymi przedmiotami. Przykładem takiego współdziałania są elementy z przedsiębiorczości, które można znaleźć w treściach geograficznych w zreformowanej szkole podstawowej. Geografia jest takim przedmiotem szkolnym, który wspierany przez otoczenie przekazuje wiedzę, kształci umiejętności i postawy bardzo zbliżone do wybranych treści z zakresu przedsiębiorczości. W efekcie powiązań międzyprzedmiotowych uczeń kształtuje swoją osobowość prywatną, społeczną i przedsiębiorczą.

Autorka publikacji dokonała analizy nowej podstawy programowej z geografii w ośmioletniej szkole podstawowej pod kątem szeroko pojętej przedsiębiorczości (tab. 1). 


\section{Tabela 1. Cele kształcenia z geografii i treści kształcenia z elementami przedsiębiorczości}

\begin{tabular}{|c|c|}
\hline $\begin{array}{l}\text { CELE KSZTAKCENIA W NOWEJ } \\
\text { PODSTAWIE PROGRAMOWEJ }\end{array}$ & $\begin{array}{l}\text { TREŚCI KSZTAŁCENIA - WYMAGANIA SZCZEGÓŁOWE, } \\
\text { W KTÓRYCH MOŻNA ZNALEŹĆ ELEMENTY PRZEDSIĘBIORCZOŚcI }\end{array}$ \\
\hline $\begin{array}{l}\text { Wiedza geograficzna } \\
\text { Poznanie zróżnicowa- } \\
\text { nych form działalności } \\
\text { człowieka w środowisku, } \\
\text { ich uwarunkowań i konse- } \\
\text { kwencji oraz dostrzeganie } \\
\text { potrzeby racjonalnego } \\
\text { gospodarowania zasoba- } \\
\text { mi przyrody }\end{array}$ & $\begin{array}{l}\text { Uczeń: } \\
\rightarrow \text { opisuje zajęcia, tradycje rodzinne i zwyczaje mieszkańców wybra- } \\
\text { nych krain geograficznych Polski; } \\
\rightarrow \text { przedstawia pozytywne i negatywne zmiany w krajobrazach po- } \\
\text { wstałe w wyniku działalności człowieka; } \\
\rightarrow \text { przedstawia znaczenie nowoczesnego przemysłu i usług w gospo- } \\
\text { darce na przykładzie Francji; } \\
\rightarrow \text { charakteryzuje przemiany w strukturze przemysłu w Niemczech } \\
\text { na przykładzie Nadrenii Północnej-Westfalii; } \\
\rightarrow \text { wyjaśnia przyczyny zmian w strukturze przemysłu Polski; } \\
\rightarrow \text { podaje przykłady różnych rodzajów usług w Polsce oraz ocenia } \\
\text { znaczenie transportu i łączności dla jakości życia mieszkańców } \\
\text { i rozwoju gospodarczego naszego kraju; } \\
\rightarrow \text { podaje przykłady osiągnięć Polaków w różnych dziedzinach życia } \\
\text { społeczno-gospodarczego oraz sukcesów polskich przedsiębiorstw } \\
\text { na arenie międzynarodowej; } \\
\rightarrow \text { przedstawia kierunki rozwoju gospodarczego Chin oraz ocenia ich } \\
\text { znaczenie w gospodarce światowej; } \\
\rightarrow \text { korzystając z danych statystycznych, określa rolę Stanów Zjedno- } \\
\text { czonych w gospodarce światowej. }\end{array}$ \\
\hline $\begin{array}{l}\text { Identyfikowanie } \\
\text { współzależności między } \\
\text { elementami środowiska } \\
\text { przyrodniczego } \\
\text { i społeczno-gospodar- } \\
\text { czego oraz związków } \\
\text { i zależności w środowisku } \\
\text { geograficznym w skali } \\
\text { lokalnej, regionalnej } \\
\text { i globalnej }\end{array}$ & $\begin{array}{l}\text { Uczeń: } \\
\rightarrow \text { identyfikuje współzależności między składnikami poznawanych } \\
\text { krajobrazów i warunkami życia człowieka; } \\
\rightarrow \text { identyfikuje związki między przebiegiem autostrad i dróg ekspre- } \\
\text { sowych a lokalizacją przedsiębiorstw przemysłowych, centrów } \\
\text { logistycznych i handlowych w obszarze metropolitalnym Wrocławia } \\
\text { oraz między transportem morskim a lokalizacją inwestycji przemy- } \\
\text { słowych i usługowych na przykładzie Trójmiasta; } \\
\rightarrow \text { identyfikuje prawidłowości w rozmieszczeniu ludności i główne } \\
\text { cechy gospodarki Australii na tle warunków przyrodniczych; } \\
\rightarrow \text { charakteryzuje region Bliskiego Wschodu pod względem cech kul- } \\
\text { turowych oraz zasobów ropy naftowej i poziomu rozwoju gospodar- } \\
\text { czego. }\end{array}$ \\
\hline
\end{tabular}




\begin{tabular}{|c|c|}
\hline $\begin{array}{l}\text { Określanie prawidłowości } \\
\text { w zakresie przestrzen- } \\
\text { nego zróżnicowania } \\
\text { warunków środowiska } \\
\text { przyrodniczego oraz życia } \\
\text { i różnych form działalno- } \\
\text { ści człowieka }\end{array}$ & $\begin{array}{l}\text { Uczeń: } \\
\rightarrow \text { wykazuje zróżnicowanie środowiska przyrodniczego } \\
\text { i charakteryzuje gospodarkę Rosji; } \\
\rightarrow \text { wykazuje znaczenie poszczególnych sektorów gospodarki w roz- } \\
\text { woju kraju oraz określa różnice w strukturze zatrudnienia ludności } \\
\text { w Polsce i w wybranych państwach europejskich; } \\
\rightarrow \text { wykazuje wpływ przemian politycznych i gospodarczych w Polsce } \\
\text { po } 1989 \text { r. na zmiany struktury zatrudnienia na przykładzie konur- } \\
\text { bacji katowickiej i aglomeracji łódzkiej; } \\
\rightarrow \text { na przykładzie Doliny Krzemowej wyjaśnia przyczyny rozwoju tech- } \\
\text { nopolii oraz jej znaczenie w rozwoju gospodarki opartej na wiedzy; } \\
\rightarrow \text { określa cechy megalopolis w Ameryce Północnej oraz wyjaśnia przy- } \\
\text { czyny powstawania slumsów w wielkich miastach na przykładzie } \\
\text { Ameryki Południowej; } \\
\rightarrow \text { określa rolę tradycyjnych i nowoczesnych działów gospodarki } \\
\text { w rozwoju wybranych krajów Afryki; } \\
\rightarrow \text { określa możliwości rozwoju gospodarczego Indii oraz przedstawia } \\
\text { kontrasty społeczne w tym kraju. }\end{array}$ \\
\hline $\begin{array}{l}\text { Umiejętności i stosowa- } \\
\text { nie wiedzy w praktyce } \\
\text { Ocenianie zjawisk i proce- } \\
\text { sów społeczno-kulturo- } \\
\text { wych oraz gospodarczych } \\
\text { zachodzących w Polsce } \\
\text { i w różnych regionach } \\
\text { świata }\end{array}$ & $\begin{array}{l}\text { Uczeń: } \\
\rightarrow \text { prezentuje niektóre przykłady budownictwa, sposobów gospodaro- } \\
\text { wania, głównych zajęć mieszkańców poznawanych obszarów; } \\
\rightarrow \text { ocenia możliwości rozwoju gospodarki morskiej w Polsce; } \\
\rightarrow \text { identyfikuje związki między rozwojem dużych miast a zmianami } \\
\text { w strefach podmiejskich w zakresie użytkowania i zagospodarowa- } \\
\text { nia terenu, stylu zabudowy oraz struktury ludności na przykładzie } \\
\text { obszarów metropolitalnych Warszawy i Krakowa. }\end{array}$ \\
\hline $\begin{array}{l}\text { Stawianie pytań, for- } \\
\text { mułowanie hipotez oraz } \\
\text { proponowanie rozwiązań } \\
\text { problemów dotyczących } \\
\text { środowiska geograficz- } \\
\text { nego }\end{array}$ & $\begin{array}{l}\text { Uczeń: } \\
\rightarrow \text { analizuje i porównuje konsekwencje stosowania różnych metod } \\
\text { ochrony przeciwpowodziowej oraz określa wpływ zabudowy obsza- } \\
\text { rów zalewowych i sztucznych zbiorników wodnych na występowa- } \\
\text { nie i skutki powodzi na przykładzie Dolnego Śląska i Małopolski; } \\
\rightarrow \text { analizuje warunki przyrodnicze i pozaprzyrodnicze sprzyjające lub } \\
\text { ograniczające produkcję energii ze źródeł nieodnawialnych } \\
\text { i odnawialnych oraz określa ich wpływ na rozwój energetyki na } \\
\text { przykładzie województw pomorskiego i łódzkiego. }\end{array}$ \\
\hline $\begin{array}{l}\text { Podejmowanie nowych } \\
\text { wyzwań oraz racjonalnych } \\
\text { działań prośrodowisko- } \\
\text { wych i społecznych }\end{array}$ & $\begin{array}{l}\text { Uczeń: } \\
\rightarrow \text { projektuje trasę wycieczki po Litwie i Białorusi uwzględniającej } \\
\text { wybrane walory środowiska przyrodniczego i kulturowego. }\end{array}$ \\
\hline $\begin{array}{l}\text { Podejmowanie kon- } \\
\text { struktywnej współpracy } \\
\text { i rozwijanie umiejętno- } \\
\text { ści komunikowania się } \\
\text { z innymi }\end{array}$ & $\begin{array}{l}\text { Uczeń: } \\
\rightarrow \text { przedstawia w dowolnej formie (np. prezentacji multimedialnej, } \\
\text { plakatu, filmu, wystawy fotograficznej) przyrodnicze i kulturowe } \\
\text { walory regionu; } \\
\rightarrow \text { projektuje trasę wycieczki krajoznawczej po własnym regionie na } \\
\text { podstawie wyszukanych źródeł informacji oraz w miarę możliwości } \\
\text { przeprowadza ją w terenie; } \\
\rightarrow \text { dyskutuje na temat form współpracy między własnym regionem } \\
\text { a partnerskimi regionami zagranicznymi; } \\
\rightarrow \text { przedstawia w dowolnej formie (np. prezentacji multimedialnej, } \\
\text { plakatu, filmu, wystawy fotograficznej) atrakcyjność „małej ojczyzny” } \\
\text { jako miejsca zamieszkania i działalności gospodarczej na podstawie } \\
\text { informacji wyszukanych w różnych źródłach. }\end{array}$ \\
\hline
\end{tabular}


Wykorzystywanie zdobytej wiedzy i umiejętności geograficznych w życiu codziennym

Uczeń:

$\rightarrow$ dokonuje oceny krajobrazu najbliższego otoczenia szkoły pod względem jego piękna oraz ładu i estetyki zagospodarowania podczas zajęć realizowanych w terenie oraz proponuje zmiany w jego zagospodarowaniu;

$\rightarrow$ wyznacza w terenie współrzędne dowolnych punktów (za pomocą mapy lub GPS);

$\rightarrow$ rozpoznaje w terenie główne obiekty charakterystyczne dla "małej ojczyzny” i decydujące o jej atrakcyjności;

$\rightarrow$ projektuje na podstawie własnych obserwacji terenowych działania służące zachowaniu walorów środowiska geograficznego (przyrodniczego i kulturowego) oraz poprawie warunków życia lokalnej społeczności.

\section{Kształtowanie postaw} Rozpoznawanie swoich predyspozycji i talentów oraz rozwijanie pasji i zainteresowań geograficznych

\section{Uczeń:}

$\rightarrow$ przyjmuje postawę współodpowiedzialności za stan środowiska przyrodniczego Polski,

$\rightarrow$ jest świadomy tego, że może mieć w przyszłości wpływ na rozwój społeczno-gospodarczy i kulturowy Polski.

Źródło: Opracowanie własne na podstawie rozporządzenia w sprawie podstawy programowej wychowania przedszkolnego oraz kształcenia ogólnego dla szkoły podstawowej z dnia 14 lutego 2017 r.

Po przeanalizowaniu nowej podstawy programowej z geografii w szkole podstawowej można zauważyć, że z elementami przedsiębiorczości wiąże się dużo treści kształcenia. Proces nabywania wiedzy i kształtowania umiejętności przedsiębiorczych może być realizowany w ramach tematów z zakresu wiedzy geograficznej, stosowania tej wiedzy w praktyce oraz kształtowania postaw. Na każdej z tych trzech płaszczyzn znajdziemy treści nauczania z zakresu geografii gospodarczej Polski, Europy i całego świata. Obecnie zagadnienia z przedsiębiorczości w geografii szkoły podstawowej będzie można realizować, dokonując charakterystyki gospodarczej wybranych krajów świata, z włączeniem Polski. Podczas uczenia wiedzy geograficznej treści przedsiębiorczości mogą być wyodrębnione podczas omawiania zmian w gospodarce Polski oraz wybranych krajów świata, m.in. Francji, Niemiec, Chin, Stanów Zjednoczonych.

W obszarze stosowania wiadomości i umiejętności w praktyce uczeń może zrozumieć wpływ różnych czynników na funkcjonowanie danego regionu poprzez: 
$\rightarrow$ ocenę zjawisk i procesów (np. przykłady budownictwa, sposoby gospodarowania i użytkowania określonych rejonów Polski i świata),

$\rightarrow$ stawianie pytań i samodzielne poszukiwanie odpowiedzi (np. wpływ warunków pozaprzyrodniczych na rozwój energetyki w Polsce),

$\rightarrow$ podejmowanie wyzwań i działań (np. projektowanie trasy wycieczki do określonego miejsca w Polsce lub na świecie),

$\rightarrow$ podejmowanie współpracy i komunikowanie się (np. prezentacje multimedialne, plakaty, filmy, wystawy dotyczące wybranych form działalności człowieka),

$\rightarrow$ wykorzystywanie wiedzy i umiejętności w życiu codziennym (np. ocena walorów pozaprzyrodniczych mających wpływ na rozwój najbliższego otoczenia).

Trzecim celem kształcenia geograficznego, w którym możemy wyodrębnić elementy z przedsiębiorczości, jest rozpoznawanie swoich predyspozycji i talentów. W tej sferze uczeń może zostać wyposażony w postawy przedsiębiorcze takie jak: pracowitość, odpowiedzialność, aktywność, umiejętność współpracy.

Nauczanie przedsiębiorczości polega na rozbudzaniu myślenia kreatywnego, rozwiązywania problemów w sposób konstruktywny, sprawnej komunikacji, dynamicznego szukania informacji, demonstracji uzyskanych informacji. Ucząc geografii w szkole podstawowej, można uczyć przedsiębiorczości. Na podstawie analizy podstawy przedsiębiorczej widać wyraźnie, że z powodzeniem na lekcjach geografii da się działać przedsiębiorczo. Wynika z tego, że nauczyciele przedmiotów nie tylko ekonomicznych mogą, a nawet we współczesnych realiach powinni, odwoływać się do przedsiębiorczości wszędzie tam, gdzie jest taka możliwość.

Dotychczas trudno było znaleźć treści kształcenia odnoszące się do przedsiębiorczości w szkole podstawowej. Treści te zaczynały być widoczne dopiero w gimnazjum. Nowa reforma, przywracając geografię do drugiego etapu kształcenia, daje możliwość nie tylko realizacji treści przedsiębiorczych na lekcjach, lecz także szansę na podejmowanie przez uczniów różnorodnych inicjatyw przedsiębiorczych. Jednym z przykładów takiej koncepcji przedsiębiorczej byłoby poprowadzenie przez uczniów na terenie szkoły wybranej działalności 
gospodarczej. Pod opieką nauczyciela uczniowie mogliby prowadzić na przykład sklepik szkolny. Taka propozycja rozwija nie tylko postawy przedsiębiorcze, lecz także wychowawcze. Dzieci w wieku 10-14 lat mogą już rozwijać swoją odkrywczość, pomysłowość, samodzielność, mądrość i komunikatywność. Taki rodzaj inicjatywy zwiększa osobiste talenty, zachęca do przedsiębiorczości, ale także zmienia mentalność młodych ludzi.

Inną formą realizacji przedsiębiorczości w geografii jest promocja postaw przedsiębiorczych poprzez przygotowywanie prezentacji i przedstawianie ich przed klasą lub całą społecznością szkolną. Podczas wykonywania pokazu dziecko zaczyna myśleć przedsiębiorczo, wykorzystując wiedzę i umiejętności w działaniu. Przykładami takich przedsięwzięć mogą być prezentacje dotyczące najbliższego otoczenia, „małej ojczyzny", ale także wybranych miast Polski lub całego świata. Na poziomie szkoły podstawowej udział uczniów w prezentacjach rozwija kreatywność, ale także samodzielność. Wypracowuje się ważny element postawy przedsiębiorczej, a mianowicie pracowitość. To właśnie ona może najbardziej zaprocentować w byciu osobą przedsiębiorczą.

Edukacja w Polsce nadal zawiera więcej wiedzy niż praktyki. Poprzez ćwiczenia praktyczne możemy dochodzić do określonej wiedzy i formułować definicje. W taki sposób rozwija się postawy przedsiębiorcze i poznaje potencjał młodego człowieka. Z doświadczenia autorki publikacji wynika, że najlepszą formą wykorzystywania wiedzy w praktyce są lekcje prowadzone metodą projektu. Na lekcjach geografii ta metoda pracy jest znana, ale w szkole podstawowej nadal rzadko stosowana. Geografia jako przedmiot szkolny daje bardzo duże możliwości stosowania metody projektu w praktyce. Przedsięwzięcia mogą objąć jedną klasę lub kilka, ale także całą społeczność szkolną. Treści prezentowane w projekcie mogą być związane z geografią, ale również z innymi przedmiotami szkolnymi. Przykładem realizacji metody projektu na geografii w szkole podstawowej jest temat „Sąsiedzi Polski”, który został zrealizowany przez autorkę publikacji w roku szkolnym 2017/2018. Projekt został przygotowany przez klasy VII i zaprezentowany całej społeczności szkolnej. Wspólna praca przy realizacji inicjatywy rozwija aktywność, kreatywność, myślenie, a także działania interpersonalne. Metoda projektu przygotowuje uczniów do praktycznego działania i daje dużą skuteczność w nauczaniu. Cytując Konfucjusza: „Usłyszałem - zapomniałem, zobaczyłem - zapamiętałem, zrobiłem - zrozumiałem", 
znajduje się potwierdzenie, że nauka szkolna winna być nastawiona głównie na praktykę, a nie na teorię.

\section{Podsumowanie}

Nauczanie przedsiębiorczości to ciągłe i systematyczne kształtowanie innowacyjności i odkrywczości. Szkoła musi współtworzyć relacje z otoczeniem i przygotowywać młodych ludzi do życia w warunkach konkurencyjnej gospodarki. Dobra edukacja, obejmująca także kształtowanie postaw przedsiębiorczych, wpływa nie tylko na możliwość osiągnięcia sukcesu w życiu zawodowym i prywatnym młodych ludzi, lecz także na szeroko rozumiany dobrobyt.

Przedsiębiorczość jako przedmiot szkolny pojawia się w nowej podstawie programowej dopiero na trzecim etapie edukacji. Dlatego są potrzebne na wcześniejszych etapach edukacji takie przedmioty jak geografia, na których kształtowane będą odpowiednie cechy u dzieci. Dzięki geografii uczniowie nabywają umiejętności planowania swojej przyszłości i aktywności w działaniu. Kształtowanie postaw przedsiębiorczych na lekcjach geografii opiera się na zasobach teoretycznych i uruchamia stosowanie wiedzy w życiu codziennym. Służy to rozwojowi osobowości człowieka, ale też ma wpływ na przyszłość i dobrą jakość życia społecznego.

Przesłankami przemawiającymi za realizacją treści przedsiębiorczych na geografii w szkole podstawowej są bliski zakres treściowy oraz zbieżność celów edukacyjnych tych przedmiotów.

Zdaniem autorki niniejszej publikacji zagadnienia przedsiębiorcze są mocno powiązane z treściami geograficznymi w zreformowanej szkole podstawowej. Edukacja przedsiębiorcza realizowana na drugim etapie edukacji może wspierać i udoskonalać ucznia. Otwartość, aktywność, pomysłowość, a także pracowitość i sumienność tworzą człowieka przedsiębiorczego w XXI w. 


\section{Bibliografia}

$\rightarrow$ Borowiec, M., Rachwał, T. (2011), Kształtowanie postaw przedsiębiorczych na lekcjach geografii wyzwaniem edukacyjnym w procesach globalizacji, „Przedsiębiorczość - Edukacja", nr 7, s. 321-332.

$\rightarrow$ Chen, C.A., Greene, P.G., Crick, A. (1998), Does entrepreneurial efficacy distinguish entrepreneurs from managers? , Journal of Business Venturing”, nr 13, s. 295-316.

$\rightarrow$ Gibb, A. (1999), Can we build effective entrepreneurship through management development, „Journal of General Management”, nr 24 (4), s. 1-21.

$\rightarrow$ Grodzicki, J. (2000), Edukacja czynnikiem rozwoju gospodarczego, Toruń: Wydawnictwo Adam Marszałek.

$\rightarrow$ Jack, S.L., Anderson, A.R. (1998), Entreprenurship education within the condition of entreprenology. Second Enterprise an Learning Conference, Centre for Entrepreneurship, Aberdeen: University of Aberdeen.

$\rightarrow$ Kabaj, M. (1997), W kierunku gospodarki opartej na wiedzy, „Polityka Społeczna", nr 4.

$\rightarrow$ Kets de Vries, F.R. (1985), The dark side of entrepreneurship, „Harvard Business Review", nr 6.

$\rightarrow$ Kurczewska, A. (2010), Problemy pomiaru intencji przedsiębiorczych, „E-mentor", $\mathrm{nr} 4$ (36).

$\rightarrow$ London, M., Smither, J.W. (1999), Empowered self-development and continuous learning, „Human Resource Management”, nr 38 (1), s. 3-15.

$\rightarrow$ Otoliński, E. (1996), Istota i kreowanie przedsiębiorczości, „Przegląd Organizacji", nr 6.

$\rightarrow$ Rozporządzenie w sprawie podstawy programowej wychowania przedszkolnego oraz kształcenia ogólnego dla szkoły podstawowej z dnia 14 lutego 2017 r.

$\rightarrow$ Safin, K. (2004), Uwarunkowania rozwoju przedsiębiorczości-próba systematyzacji [w:] K. Jaremczuk (red.), Uwarunkowania przedsiębiorczości, Tarnobrzeg: Wydawnictwo PWSZ, s. 45. 
$\rightarrow$ Salomon, G.T., Duffy, S., Tarabishy, A. (2002), The state of entrepreneurship education in the United States: a nationwide survey and analysis, "International Journal of Entrepreneurship Education", nr 1 (1), s. 65-86.

$\rightarrow$ Shapero, A., Sokol, L. (1982), Social dimensions of entrepreneurship, [w:] C.A. Kent, D.L. Sexton, K.H. Vesper (red.), Encyclopedia of entrepreneurship, University of Illinois: Prentice Hall, s. 72-90.

$\rightarrow$ Wach, K. (2014), Europeanisation of Entrepreneurship Education in Europe - Looking Back and Looking Forward, „Horyzonty Wychowania”, nr 13 (26), s. 11-31.

$\rightarrow$ Wieloński, A. (2003), Przemysł nowej gospodarki, „Prace Komisji Geografii Przemysłu Polskiego Towarzystwa Geograficznego", nr 6, s. 21-26.

$\rightarrow$ Zajączkowska-Jakimiak, S. (2002), Wiedza i technologia w erze globalizacji, [w:] Globalizacja, mechanizmy i wyzwania, B. Liberska (red.), Warszawa: PWE. 


\section{Netografia}

$\rightarrow$ National Content Standards for Entrepreneurship Education: Nurturing the Entrepreneurial Spirit, www.entre-ed.org/Standarts_Toolkit/nurturing.html [dostęp 8.10.2018]. 